\title{
His Faithfulness is from Generation to Generation (Ps 100:5c): The Coherence of the Eleven Compositions Psalms 90-100
}

\author{
Pieter Van Der Lugt (DokKum, The Netherlands) ${ }^{1}$
}

\begin{abstract}
Psalms 93-100 are almost generally considered an individual cycle of "YHWH King-psalms." Here it is argued that Ps 100 is the concluding composition of a cycle consisting of eleven psalms which starts at Ps 90. This major cycle is composed of two sub-cycles of five psalms, Pss 90-94 and Pss 96-100, which frame a pivotal composition of eleven poetic lines, $P$ s 95. The rhetorical design of the main cycle is determined by content and several formal features. The latter rhetorical means include the use of meaningful numbers like 7, 11, 26, and the strategic positioning of unique significant vocabulary as guide lexemes.
\end{abstract}

KEYWORDS: Psalms 90-100; Psalter Book IV; YHWH-Kingship-Psalms (YHwh-Melech-Psalms); Composition(s) of Psalms; Structure of Psalms (Groups); Biblical Hebrew Poetics.

\section{A INTRODUCTION}

Exegetes generally assume that Book IV of the Psalter can be divided into three cycles of poems, Pss 90-92, 93-100 and 101-106. ${ }^{2}$ In this context, Pss 93-100 are

* Article submitted: 2019/03/04; peer reviewed: 2019/05/18; accepted: 2019/07/16. Pieter van der Lugt, "His Faithfulness is from Generation to Generation (Ps 100:5c): The Coherence of the Eleven Compositions Psalms 90-100," OTE 32 no. 2 (2019): 606-635. DOI: https://doi.org/10.17159/2312-3621/2019/v32n2a18.

1 I thank Gianni Barbiero and Beat Weber for their comments on a previous draft of this investigation.

2 Erich Zenger, "Das Weltenkönigtum des Gottes Israel (Ps. 96-106)," in Der Gott Israels und die Völker. Untersuchungen zum Jesajabuch und zu den Psalmen (ed. Norbert Lohfink and Erich Zenger; SBS 154; Stuttgart: Katholisches Bibelwerk, 1994), 151-178 (156-177); Thomas Krüger, "Psalm 90 und die 'Vergänglichkeit des Menschen'," Bib. 75 (1994): 191-219 (213-216); Frank-Lothar Hossfeld and Erich Zenger, Psalmen 51-100 (HThKAT; Freiburg: Herder, 2000), 613-614; Erich Zenger, "Theophanien des Königsgottes JHWH: Transformationen von Psalm 29 in den Teilkompositionen Ps 28-30 und Ps 93-100," in The Book of Psalms. Composition and Reception (ed. Peter W. Flint and Patrick D. Miller; VTSup 99 / FIOTL 4; Leiden: Brill, 2005), 407-442 (422); Johannes Schnocks. Vergänglichkeit und Gottesherrschaft. Studien zu Psalm 90 und dem vierten Psalmenbuch (BBB 140; Berlin: Philo, 2002), 191211; Egbert Ballhorn, Zum Telos des Psalters. Der Textzusammenhang des Vierten und Fünften Psalmenbuches (Ps 90-150) (BBB 138; Berlin: Philo, 2004), 81-86; Martin Leuenberger, Konzeptionen des Königtums Gottes im Psalter. Untersuchungen zu Komposition und Redaktion der theokratischen Bücher IV-V im Psalter (ATANT 83; 
generally defined as a cycle of "YHWH-King-psalms." 3 At the same time, especially Ps 94 has often been considered to be anomalous in this group. Additionally, the conspicuous relationships between Pss 94 and 92 (which are generally recognized) do not favour the idea of a main break after Ps 92. In this contribution it will be argued that there is no main break, be it editorial, structural, or conceptual, after Ps 92. The evidence suggests that Pss 90-100 represent a deliberately designed cycle of eleven psalms. This major cycle consists of two sub-cycles of five psalms (Pss 90-94 and 96-100), which frame a pivotal composition of eleven poetic lines, Ps 95. I am honoured to dedicate these observations to Prof Phil Botha on the occasion of his $65^{\text {th }}$ birthday.

\section{B THE STRUCTURE OF PSALMS 90-94, SUB-CYCLE I}

Psalms 90-94 (Sub-cycle I) are to be taken as a first sub-cycle of five psalms in the broader context of Pss 90-100. That is to say, the first main break in the cycle Pss 90-100 comes after Ps $94 .{ }^{4}$ In terms of unique lexical similarities, guide lexemes, and content, this sub-cycle displays indications of a simultaneously linearly alternating and a concentric design: 90.91.92.93.94 > A.B.A'.B'.A" and A.B.X.B'.A'. 5

Zürich: Theologischer Verlag, 2004, 129-172; Ulrich Dahmen, “'Gepriesen sei der Herr, der Gott Israels, vom Anfang bis ans Ende der Zeiten' (Ps 106,48). Beobachtungen zur Entstehungsgeschichte des Psalters im vierten und fünften Psalmenbuch," BZ 49 (2005): 1-25 (8); Phil J. Botha, "Psalm 91 and its Wisdom Connections," OTE 25 (2012): 260276 (271-274); for various divisions of Book IV by other scholars (Ribera-Mariné, Koch, Wilson, Howard, Auffret, Millard, Koenen), see Leuenberger, Konzeptionen, 126-128, and Ballhorn, Telos, 63-70.

3 See also Henk Leene, "The Coming of YHWH as King: The Complementary Character of Psalms 96 and 98," in Unless Some One Guide Me ...: Festschrift for Karel A. Deurloo (ed. Janet W. Dyk; ACEBTSup 2; Maastricht: Shaker, 2001), 211-228 (215): "contextual links that are really meaningful do not seem to reach back beyond Psalm 93 nor forward beyond Psalm 100." Nevertheless, in Pss 94 and 100 YHWH is not defined as מלך ("King").

4 Similarly David M. Howard Jr., "A Contextual Reading of Psalms 90-94," in The Shape and Shaping of the Psalter (ed. J. Clinton McCann; JSOTSup 159; Sheffield: Sheffield Academic Press, 1993), 108-123; idem., The Structure of Psalms 93-100 (BJSUCSD 5; Winona Lake, IN: Eisenbrauns, 1997), 166; idem., "Psalm 94 among the Kingship-of-Yhwh Psalms," $C B Q 61$ (1999): 667-685 (669 n. 5). Following earlier publications by Howard, Marvin E. Tate, Psalms 51-100 (WBC 20; Dallas, TX: Word Books, 1990), 489, surmises that Pss 90-94 "form a five-psalm unit with some coherence of meaning and function."

5 These patterns do not detract from the often significant links which exist between immediately consecutive psalms, e.g. between Pss 92 and 91; for the latter relationship, see Klaus Koenen, Jahwe wird kommen, zu herrschen über die Erde. Ps 90-110 als Komposition (BBB 101; Weinheim: Beltz Athenäum, 1995), 54-56; Pieter van der Lugt, 
608 Van der Lugt, "His Faithfulness," OTE 32/2 (2019): 606-635

\section{$1 \quad$ Guide lexemes}

Before pointing out the alternating relationships between Pss 90-94 in terms of content, I will display the linearly alternating design of the sub-cycle in terms of unique recurrent vocabulary that acts as guide lexemes, in alphabetical order. A $\dagger$ (dagger) indicates that the lexeme or phrase does not occur outside Sub-cycle I, that is to say, not elsewhere in the main cycle Pss 90-100.

Table I

\begin{tabular}{|c|c|c|c|c|c|}
\hline & $90(\mathrm{~A})$ & $91(\mathrm{~B})$ & $92\left(\mathrm{~A}^{\prime}\right)$ & 93 (B') & $94\left(A^{\prime \prime}\right)$ \\
\hline און (1) ("evill") (1) & $10 \mathrm{c}$ & & $8 \mathrm{~b} .10 \mathrm{c}$ & & 4b.16b.23a \\
\hline - & & & $12 \mathrm{c}$ & & $9 \mathrm{a}$ \\
\hline (2) אלהינו & $17 \mathrm{a}$ & & $14 \mathrm{~b}$ & & $23 \mathrm{c}$ \\
\hline + †בקר & 5b.6a.14a & & $3 \mathrm{a}$ & & \\
\hline (3) † בבקר חסדך & $14 \mathrm{a}$ & & $3 a$ & & \\
\hline רין & & & $7 b$ & & $7 b .8 a$ \\
\hline † בער // וכסילר| & & & 7 & & 8 \\
\hline (4) (4) & $14 \mathrm{a}$ & & $3 a$ & & $18 \mathrm{~b}$ \\
\hline لשר & & & $16 a$ & & $15 b$ \\
\hline (6) לב/לבב & $12 \mathrm{~b}$ & & & & $15 b$ \\
\hline † † מחשבה & & & $6 \mathrm{~b}$ & & $11 \mathrm{a}$ \\
\hline † מעשה & $17 a+b$ & & $5 b .6 a$ & & \\
\hline (7) † מעשה + יד & $17 a+b$ & & $5 b$ & & \\
\hline † † מתי & $13 \mathrm{a}$ & & & & $3 a+b .8 b$ \\
\hline † עד מתי & $13 a$ & & & & $3 a+b$ \\
\hline (8) † פעלי און & & & $8 b .10 c$ & & $4 b .16 b$ \\
\hline (9) † פעלך & $16 a$ & & $5 \mathrm{a}$ & & \\
\hline (10) צדיק & & & $13 a$ & & $21 \mathrm{a}$ \\
\hline$\sqrt{\gamma}+(11)$ & $6 a$ & & $8 \mathrm{~b}$ & & \\
\hline (12) צור & & & $16 \mathrm{~b}$ & & $22 b$ \\
\hline V) רנן & $14 \mathrm{~b}$ & & $5 b$ & & \\
\hline Vמחמ & $14 b .15 a$ & & $5 \mathrm{a}$ & & \\
\hline ل & $3 a+b .13 a$ & & & & $2 \mathrm{~b} .15 \mathrm{a} .23 \mathrm{a}$ \\
\hline & & & $12 \mathrm{c}$ & & $9 \mathrm{a}$ \\
\hline (16) † ארך ימים & & $16 \mathrm{a}$ & & $\overline{5 \mathrm{c}}$ & \\
\hline
\end{tabular}

\section{Notes:}

(1) For the expression פעלי און ("evildoers"), see below.

(2) In Pss 90 and 94 אלהינו ("our God") is strategically positioned in the final poetic line of the psalm; ${ }^{6}$ see further אלהינו in 95:7a, 98:3d, 99:5a.8a.9a+c.

Cantos and Strophes in Biblical Hebrew Poetry III: Psalms 90-150 and Psalm 1 (OTS 63; Leiden: Brill, 2014), 45.

6 In the Hebrew Bible a "poetic line" or "line of poetry" is composed of two or three cola. In the Psalter a poetic line generally coincides with a Masoretic verse. 
(3) For the expression לובבקר חסדך ("in the morning your steadfast love") in the Psalter, see also 59:17b and 143:8a.

(4) For the noun ("steadfast love"), see also Table II.

(5) In both cases $\sqrt{ }$ ' ("to be right") occurs in the last line of Canto II (in Ps 92 it is also the last line of the poem); see further 96:10c, 97:11b, 98:9d, 99:4b.

(6) In both cases the noun לבב/לב ("heart") is strategically positioned in the last colon of Canto II; see further 95:8a.10b and 97:11b.

(7) For מעשה + יד in the Psalter, see also 28:4a.5b and 143:5c.

(8) In 92:8b.10c and 94:4b we find כל פעלי און ("all evildoers").

(9) Cf. פעלי ("my doing") in 95:9b (see Table V); the noun פל פלי ("doing") does not occur elsewhere in Pss 90-100.

צדיק (10) In both cases in the opening strophe of the concluding 4-line canticle; see also in 97:11a.12a.

(11) In both cases צוץ ("to blossom") is found in the last line of Canto I.

(12) The noun צור ("rock") also occurs in 95:1b (see Table V).

(13) For רנן ("to shout [for joy]"), see also Table II and 95:1a (Table V).

(14) See also שמח ("to rejoice") in 97:1b.8a.12a and 100:2a.

(15) See also שמע ("to hear") in 95:7d and 97:8a.

(16) In both cases, the expression ("length of days") is strategically positioned in exactly the final poetic line of the psalms concerned (responsion on psalm level). For in the Psalter, see also 21:5b and 23:6d.

In terms of guide lexemes, the linearly alternating design of Sub-cycle I is especially confirmed by און ("evil"), אלהינו ("our God") and ("steadfast love") because within this sub-cycle these words occur only in each of the A-psalms, while the strategically positioned expression ("length of days") occurs only in the B-psalms. In the context of the five psalms Sub-cycle I is composed of, Ps 92 takes up a central position. In terms of guide lexemes, this central position is reinforced by the strategic positioning of לבב/לב ("heart") in the last colon of the second canto of Pss 90 and 94, by the strategic positioning of שלהינו ("our God") in the final lines of Pss 90 and 94, by שוב מתי ("to return") and ("how long?") in Pss 90 and 94. These guide lexemes occur only at the "seams" of Sub-cycle I. The strategic positioning of the expression ארך ימים in the final poetic line of Pss 91 and 93 further underscores the concentric aspect of Subcycle I and the central position of Ps 92.

\section{Rhetorical design and content}

The lexical features pointing to a linearly alternating pattern in Pss 90-94 coincide with indications of a linearly alternating pattern in terms of rhetorical design and content. 
a Specific connections between the A-psalms

Although there is an obvious difference between Pss 90 and 92 (A and A'), these compositions definitively have corresponding features. Ps 92 is the song of thanksgiving of an individual; in Canticles I.1 and II.1 (vv. 2-5 and 9-12) the psalmist continually speaks in the first person singular; note vv. 5 and $12 .{ }^{7}$ Ps 90 is a collective lament, the psalmist speaks in the first person plural. Nevertheless, especially in terms of unique vocabulary, the opening canticle of Ps 92 (vv. 2-5) clearly harks back to the concluding canto of Ps 90 (vv. 13-17); see משקר חסדך ("Wor) ("in the morning your steadfast love"), מעשה + ("work" + "hand"), פעלך ("your doing"), רנן ("to shout [for joy]"), שמח ("to rejoice") in Table I. Additionally, in both cases צוץ ("to blossom") occurs exactly in the concluding line of Canto I. In Ps 90 a human being in general is "compared with grass" (כחציר) which "blossoms" (vv. 5-6), while in Ps 92 it is especially godless people who are "compared with grass" (כמו עשב) which "blossoms" (v. 8). Simultaneously, in both cases, their prosperity is only temporary, they quickly disappear (90:6b, 92:8c). Nevertheless, the difference between a human being in general and godless people may imply that there is hope for the righteous (in Israel); see also the concluding canticle of Ps 92: "the righteous will flourish like the palm tree [...]" (vv. 13-16).

"Psalm 94 comes full circle in the first section of Book IV by echoing Psalm 90 as well as $92 .{ }^{\prime \prime}$ As is regularly pointed out by exegetes, Pss 92 and 94 (A' and A") display significant wisdom features. The wisdom section 94:8-11.1215 (Canticles II.1 and II.2) closely echoes 92:6-8.13-16 (Canticles I.2 and II.2). The pericopes in question speak of fools who have no understanding of God's works (92:6-8, 94:8-11). They do not know God's "thoughts" (92:6b), while God knows the futile "thoughts" of men (94:11). On the contrary, the righteous will prosper in the future (92:13-16; 94:12-15). Pss 92 and 94 also correspond because in a substantial part of both compositions the psalmist speaks in the first person singular; see 92:2-5.9-12 (Canticles I.1 and II.1; note the concluding lines vv. 5 and 11-12 respectively) and 94:16-23 (Canto III). ${ }^{9}$ Finally, as is the case in Ps 94, the cantos of Ps 92 are composed of mostly 4-line canticles. ${ }^{10}$

7 For the rhetorical structure of Pss 90-100 in terms of cantos, canticles and strophes, see Van der Lugt, Cantos III.

8 Howard, Psalms 93-100, 173; similarly Howard, "Psalms 90-94," 121; Howard, "Psalm 94," 669. Howard, "Psalms 90-94," 114-117, has convincingly argued that Ps 94 is well suited to its present position; similarly Howard, "Psalm 94" and cf. Tate, Psalms 51-100, 488-489.

9 For this phenomenon, cf. also 91:2.9a. Among other things, because pericopes in the first person singular do not occur elsewhere in Pss 93-100, Zenger, "Theophanien," 428 , concludes that Ps 94 is a secondary insertion in the cycle concerned.

10 Van der Lugt, Cantos III, 37, 52. 
At the same time, Ps 94 (A") is to be considered the provisional reaction to the communal prayer for deliverance phrased in the concluding Canto III of Ps 90 (A; vv. 13-17). ${ }^{11}$ Psalm 90 concludes with a vehement prayer for deliverance: 'turn, YHWH, how long? // and have compassion with your servants'; v. 13). This prayer straightforwardly implores God to change his mind. According to tradition, it is only Moses who dared to speak to God in this way (Ex 32:12); for אפך ("your anger") and ("misfortune"), see Ps 90:7.11 and 90:15 respectively. This connection also explains the heading of Ps 90. Subsequently, within the main cycle Pss 90-100 it is further only Ps 94:1-2 which expresses a prayer comparable to 90:13-17: "O God of vindication, YHWH // O God of vindication, shine forth"; 94:1). עד מתי ("how long?") in 94:3a+b and 90:13a, שוב in 94:2b and 90:13a (for $\sqrt{ }$ in , see also Table I). ${ }^{13}$ In 94:5-7 (Canticle I.2) we find the description of distress; for this theme, cf. especially 90:7-12 (Canto II). 94:1-7 as well as 90:7-17 represent a communal prayer for deliverance; for the collective aspect of 94:1-7, see עמך ("your people") and נחלתך ("your heritage") in v. 5. ${ }^{14}$ In contrast to Ps 90, in Ps 94 the communal prayer for deliverance is followed by a sustained expression of trust phrased in especially vv. 12-15 (Canticle II.2); note "yes, YHWH will not desert his people // and his heritage He will not forsake" (v. 14). Additionally, in terms of poetic design, Pss 90 and 94 stand out in the main cycle Pss 90-100 as a whole by being composed of three cantos (90:1-6,7-12,13-17 and 94:1-7,8-15,16-23), while the other psalms are all composed of two cantos.

\section{b Specific connections between the B-psalms}

At first sight, it may seem that Pss 91 and 93 (B and B’) do not have much in common. Moreover, as noted before $(\S \mathrm{A})$, most scholars take it for granted that Ps 93 represents the beginning of a cycle of poems defined as "YHWH-Kingpsalms." However, different from the other so-called YHWH-King-psalms which all unsuspectingly sing the praises of God's creative power and preponderance over all peoples of the earth and pagan gods, Ps 93 points out the mythological, hostile forces which may threaten YHWH's creative actions and royal authority. In this respect, note the repetitive reference (3x) to ("rivers") in the pivotal tricolon v. 3; see also מים רבים ("many waters"; v. 4a) and the phrase אדירים משברי ים ("mighty are the breakers of the sea"; v. 4b). Additionally, Ps 93 goes without explicit calls to honour YHWH, while such appeals play a structuring role in Pss 95-100 (see below). This special content of Ps 93 is positively paralleled by the

11 Cf. Howard, Psalms 93-100, 173, and Howard, "Psalm 94," 669-670.

12 MT reads הופיע, haplography.

13 For the phenomenon that the opening canticle of Ps 94 refers to the concluding canto of Ps 90, cf. above about the relationship between the opening canticle of Ps 92 (vv. 25) and the concluding canto of Ps 90.

14 Cf. Howard, "Psalm 94," 669: "Significantly, Psalms 90 and 94 are the only two psalms in book 4 that contain a section of lament until we reach Psalm 102." 
leading idea of Ps 91. Psalm 91 is larded with references to all kinds of mysterious dangers God's devotees (v. 14) may encounter: trap and plague (v. 3b), terror, arrow, plague (once again) and destruction (vv. 5-6), and lion, adder, young lion and serpent (v. 13). Amidst these dangers which may threaten the psalmist he repeatedly asserts that God is his refuge (יוהו מחסי; vv. 2a, 9a, marking the opening 2-line strophes of the cantos). By highlighting YHWH's unshakable kingship amidst the threats of all kinds of primordial dangers, Ps 93 makes it clear that this trust in God is not unfounded. The concluding lines of the strophes vv. 1-2, 3-5 (vv. 1c-2 and 5) emphasize the firmness of God's supremacy; note "your throne is established from of old" (v. 2a) and "your precepts are firm" (v. 5a). This main idea of Ps 93 is the guarantee for the trust that God's devotees nurse. ${ }^{15}$ These observations are in line with the conspicuous positioning of the unique expression ארך ימים ("length of days") in the concluding lines of Pss 91 and 93 (Table I), a phenomenon which underlines the connection between the psalms in question.

\section{c Psalm 92 in the centre}

Ps 92 stands out in Sub-cycle I not only in terms of its central position $(<2+\mathbf{1}+2$ psalms) and the symmetric patterns of guide lexemes, but also because of its content. ${ }^{16}$ Within the sub-cycle, Ps 92 stands out as an uncompromising song of praise. From the beginning to the end the composition speaks of the declaration of God's steadfast love and reliability; note להגיד ("to declare") in vv. 3a.16a and the rhetorical centre v. 9, ואתה מרום לעלם יהוה ("and you are the Exalted forever, YHWH"). ${ }^{17}$ The psalmist not only asserts that it is good to give thanks to the LORD (v. 2), but he himself straightforwardly sings the praises of God's works and unfathomable thoughts (vv. 6-8; Canticle I.2). These observations are supported by the fact that $\sqrt{ }$ ("to sing praise"; v. 2b) does not occur elsewhere in Subcycle I, but features prominently in Ps 98 (the central poem of Sub-cycle II) and Ps 95 (the central poem of the main cycle; Table V). Moreover, the special meaning of the psalm within the sub-cycle is also indicated by its heading, מזמור

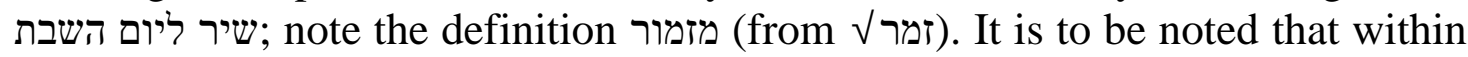
our sub-cycle, it is only the opening Ps 90 and the pivotal Ps 92 which have a heading; cf. below about the headings of Pss 98 and 100 within Sub-cycle II, once again defining these compositions as מזמור.

15 The thematic connections between Pss 93 and 91 are ignored by Howard, "Psalms 90-94," Koenen, Jahwe wird kommen; Schnocks, Vergänglichkeit, 219-20, and Leuenberger, Konzeptionen.

16 Tate, Psalms 51-100, 489, already observed that the unit Pss 90-94 "is gathered around the significance of the Sabbath" (see the heading of Ps 92).

17 The colon v. 9 is framed by $\mathbf{5 2}$ words at both sides; similarly Howard, "Psalms 9094," 113-114, and see further Van der Lugt, Cantos III, 41. 


\section{THE STRUCTURE OF PSALMS 96-100, SUB-CYCLE II}

Like Pss 90-94, Pss 96-100 represent a coherent sub-cycle of five poetic compositions (Sub-cycle II). In terms of significant vocabulary, this is explicitly indicated by the expression ("his faithfulness") which is strategically positioned as exactly the final word of Pss 96 and 100 (96:13d and 100:5c). And like Pss 90-94, in terms of unique lexical similarities and content, Pss 96-100 display indications of a linearly alternating and concentric design: Pss 96.97.98.99.100 > C.D.C'.D'.C" and C.D.X.D'.C'. ${ }^{18}$

\section{Guide lexemes}

Before pointing out the alternating relationships between the psalms of Sub-cycle II in terms of content, I will display these relationships in terms of unique recurrent vocabulary that acts as guide lexemes, in alphabetical order. A $\dagger$ (dagger) indicates that the lexeme or phrase does not occur outside the sub-cycle, that is to say, not elsewhere in Pss 90-100.

Table II

\begin{tabular}{|c|c|c|c|c|c|}
\hline & $96(\mathrm{C})$ & 97 (D) & $98\left(C^{\prime}\right)$ & 99 (D') & $100\left(C^{\prime \prime}\right)$ \\
\hline (1) אמונתו & $13 \mathrm{~d}$ & & $3 \mathrm{a}$ & & $5 \mathrm{c}$ \\
\hline בואי & $8 b .13 a$ & & $9 a$ & & $2 b .4 a$ \\
\hline † †רך & $2 \mathrm{a}$ & & & & $4 c$ \\
\hline † ברכו שמו & $2 \mathrm{a}$ & & & & $4 c$ \\
\hline (3) גוי & 3a.10a & & $2 b$ & & \\
\hline (4) הריעו ל- + יהוה & & & $4 a .6 b$ & & $1 \mathrm{a}$ \\
\hline (5) † הריעו ליהוה כל הארץ & & & $4 a$ & & $1 \mathrm{a}$ \\
\hline (6) (6) חסדו & & & $3 a$ & & $5 b$ \\
\hline (7) † חסדו + אמונתו & & & $3 a$ & & $5 b-c$ \\
\hline (8) חצרותיו & $8 b$ & & & & $4 \mathrm{~b}$ \\
\hline † †רעם הים ומלאו & $11 \mathrm{~b}$ & & $7 a$ & & \\
\hline (9) ישעע & $2 b$ & & 1c. $2 \mathrm{a} .3 \mathrm{~d}$ & & \\
\hline (10) [...] // לפני יהוה כי בא & 13 & & 9 & & \\
\hline ( † + נפלאות & $3 b$ & & $1 \mathrm{~b}$ & & \\
\hline (11) רועי & & & $4 a .6 b$ & & $1 \mathrm{a}$ \\
\hline V) רנן & $12 b$ & & $4 \mathrm{~b} .8 \mathrm{~d}$ & & $2 b$ \\
\hline (13) רנן V + שמחV & $11-12$ & & & & $2 a-b$ \\
\hline ل שיר & $1 \mathrm{a}+\mathrm{b} .2 \mathrm{a}$ & & $1 \mathrm{a}$ & & \\
\hline (15) † שירו ליהוה שיר חדש & $1 \mathrm{a}$ & & $1 \mathrm{a}$ & & \\
\hline
\end{tabular}

18 These patterns do not detract from the often significant links between immediately consecutive psalms, e.g. between Pss 96 and 97; for this relationship, see Howard, Psalms 93-100, 177, and Leene, “Coming," 219-220. 
614 Van der Lugt, “His Faithfulness,” OTE 32/2 (2019): 606-635

\begin{tabular}{|c|c|c|}
\hline † אהב & $10 \mathrm{a}$ & $4 a$ \\
\hline (16) יהוה מלך & $1 \mathrm{a}$ & $1 \mathrm{a}$ \\
\hline (17) משפט & $2 b .8 c$ & $4 a+c$ \\
\hline ("cloud") ענן ("clo & $2 a$ & $7 \mathrm{a}$ \\
\hline (צ' ציון & $8 \mathrm{a}$ & $2 a$ \\
\hline (18) שמר & $10 \mathrm{~b}$ & $7 b$ \\
\hline
\end{tabular}

\section{Notes:}

(1) אמונתו ("his faithfulness") is strategically positioned at exactly the very end of Pss 96 and 100. The deliberately designed positioning of ("with faithfulness") at the end of Ps 96 (C-psalm) is demonstrated by the corresponding concluding strophe of Ps 98 (C'-psalm) which concludes with ועמים במישרים ("and peoples with equity"; v. 9d). See also note (7).

(2) For בוא ("to come"), see also 90:12b (Table III) and 95:6a.11b (Table V).

(3) For ("people”), see also 94:10a (Table III).

(4) For ("to shout"), see below.

(5) The phrase is strategically positioned at exactly the beginning of the second canto of Ps 98 and the beginning of Ps 100 .

(6) חסד ("steadfast love"), see also Table I; cf. חסידים in 97:10b.

(7) For, see also 92:3 (Table III).

(8) See also חצרות ("court-yards") in 92:14b (Table III).

(9) For $\sqrt{ }$ ישע hiph'il ("to save"), see also 91:16b and 95:1b.

(10) In both cases the concluding strophe of the psalm; for $\sqrt{ }$ (96:13b and 98:9b), see also 94:2a (Table III).

(11) For רוע ("to shout"), see also 95:1b.2b (Table V).

(12) For רנן ("to shout [for joy]"), see also Table I and 95:1a (Table V).

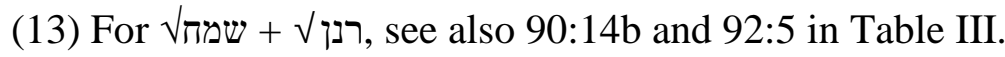

(14) It is noteworthy, that the noun ("song") also occurs in the heading of Ps 92.

(15) Strategically positioned at the very beginning of the psalm.

(16) In 97:1a and 99:1a יהוה מלך ("YHWH reigns") is strategically positioned at the very

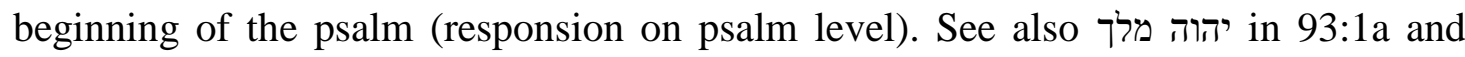
96:10a. Cf. מלך גדול ("great King”) referring to God in 95:3b and המלך יהוה ("the King YHWH") in 98:6b.

(17) For the noun משפט, see also 94:15a.

(18) For שמר ("to keep"), see also 91:11b (Table IV).

In terms of guide lexemes, the linearly alternating design of Sub-cycle II is especially confirmed by רואר, אמונתו, and , רנן , because these words occur only in each of the C-psalms. From this perspective, the D-psalms smoothly fit this ותחל תגל הארץ (the earth rejoices"; 97:1a) and "thating design. Compare also הארץ ("and the earth writhes"; 97:4b) with תנוט הארץ ("the earth quakes"; 99:1b) in the "opening" lines of Pss 97 and 99 respectively. In the context of the five psalms Sub-cycle II is composed of, Ps 98 takes up a central position. In terms of 
guide lexemes, this central position is reinforced by the unique lexical similarities

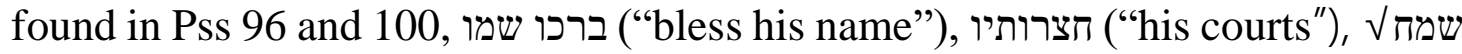
("to rejoice") + רנן ("to shout [for joy]"), and the cluster of guide lexemes marking out Pss 97 and 99, which all point to a concentric aspect of Sub-cycle II. In this respect, see also the strategic positioning of אמונתו at the very end of Pss 96 and 100.

\section{Rhetorical design and content}

The lexical features pointing to a linearly alternating pattern in Pss 96-100 coincide with indications of a linearly alternating pattern in terms of rhetorical design and content. Within the sequence Pss 96-99, Howard already discerned the arrangement of "an alternating A-B-A'-B' pattern." ${ }^{19}$ In my view, as already suggested by the guide lexemes featuring in Sub-cycle II, Ps 100 perfectly fits this alternating pattern. ${ }^{20}$

\section{a Specific connections between the C-psalms}

Pss 96, 98 and 100 (the C-psalms) are determined by an ongoing summons to praise the LORD at the beginning of the main parts, the cantos. In Ps 96 the call שירו ליהוה שיר חדש "sing to YHWH a new song”) opening Canto I (v. 1a; see also vv. 2a and 3a) immediately expresses the leading idea of the poem and is reinforced by the call הבו ליהוה משפחות עמים ("ascribe to YHWH, you families of

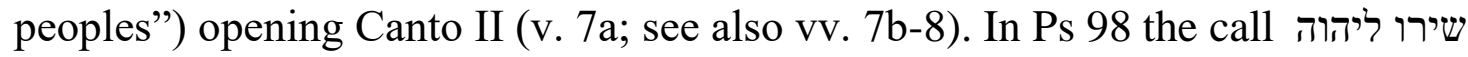
opening Canto I (v. 1a) immediately expresses the leading idea of the poem and is reinforced by the call הריעו ליהוה כל הארץ ("raise a shout for YHWH, all the earth") opening Canto II (v. 4a). Subsequently, the latter phrase (98:4a) is strategically positioned at the beginning of Ps 100 (v. 1a), opening the first 2-line strophe (vv. 1-3). In Ps 100 the opening summons is taken up by בואו שעריו בתודה ("enter his gates with thanksgiving"), opening the second 2-line strophe (vv. 45). In Pss 96, 98 and 100 these calls are followed by the reasons why a praise is appropriate; note כי 96:4a.5a.13a+b, 98:1b.9a, 100:3a.5a. To put it briefly: for great is the LORD!

\section{b Specific connections between the D-psalms}

Pss 97 and 99 (the D-psalms) are also determined by an ongoing call to praise the LORD. ${ }^{21}$ However, the rhetorical structure of Pss 97 and 99 (the D-psalms) is the mirror image of Pss 96, 98 and 100 (the C-psalms) described above. Different

19 Howard, Psalms 93-100, 154; similarly Tate, Psalms 51-100, 509, following earlier publications by Howard.

20 For the correspondences between Pss 96, 98 and 100, cf. also Zenger, "Theophanien," 431-432 and 437. For the relationship between Pss 96 and 100, see Howard, Psalms 93-100, 153-154; for the relationship between Pss 98 and 100, see Howard, Psalms 93-100, 162-164.

21 For the relationship between Pss 97 and 99, see Howard, Psalms 93-100, 157-159. 
from the C-psalms, Pss 97 and 99 immediately open with the reason why a tribute is appropriate: יהוה מלך ("YHWH reigns"; 97:1a and 99:1a). This festive proclamation goes back to ממרו בגוים יהוה מלך ("say among the nations: YHWH reigns") in Ps. 96:10a and הריעו לפני המלך יהוה מלד ("raise a shout before the King, YHWH") in 98:6b. Subsequently, the tribute itself is phrased in the concluding lines of the cantos: הגידו השמים צדקו [.... ("the heavens proclaim his righteousness [...]"; 97:6), שמחו צדקים ביהוה [...] ("rejoice, you righteous ones, in YHWH [...]"; 97:12), רוממו יהוה אלהינוה [...] ("exalt Yhwh our God [...]”; 99:5.9). For Ps 97, see also the hymnic line כי אתה יהוה \" עליון על כל הארץ ("..." ("yes, you, YHWH, // are the Most High over all the earth [...]"; 97:9, the line which parallels 97:12).

The opening canto of Ps 97 (vv. 1-6) describes a theophany. Apart from other references (e.g. Ps. 18:8-16), this theophany reminds of Ex 19:16-20 and 20:21, the theophany at Mount Sinai in the presence of Moses and the people of Israel. ${ }^{22}$ From this perspective, the reference to Moses in the concluding canto of Ps 99 (v. 6a) highlights the thematic connection between the D-psalms. ${ }^{23}$ At first sight, the wisdom flavour of the concluding strophe of Ps 97 (vv. 10-12) does not fit the preceding ideas expressed in vv. 1-9, which speak of the revelation of God's kingship in nature (vv. 1-6) and the joy of the people of Israel over this manifestation (vv. 7-9). ${ }^{24}$ Nevertheless, the carefully designed poetic framework of Ps 97 demonstrates that vv. 10-12 represent an integrated element of the composition. ${ }^{25}$ In the context of Sub-cycle II, 97:10-12 also has a structuring function in terms of meaning. The opening canto of Ps 99 (vv. 1-5) speaks of God as the royal Legislator of his people and in this way links up with the concluding strophe of Ps 97; compare ועז מלך משפט אהב ("and the might of the King loves

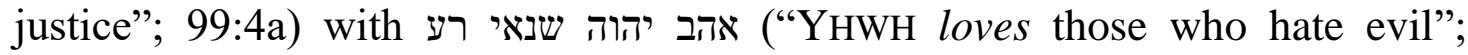

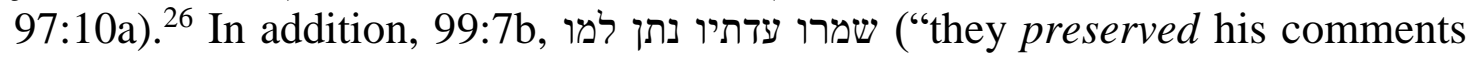
and the decrees he gave them"), makes it clear which people belong to the "loyal ones" spoken of in 97:10b, שמר נפשות חסידיו ("he preserves the lives of his loyal ones"). The relationship between the concluding canto of Ps 97 (vv. 7-12) and the opening canto of Ps 99 (vv. 1-5) is further underlined by the reference to Zion (97:8a and 99:2a). That is to say, from a thematic perspective Pss 97 and 99 have

22 ענן ("cloud"; Ps 97:2a and Ex 19:16a), ערפל ("darkness"; Ps 97:2a and Ex 20:21b), ברקים ("lightnings"; Ps 97:4a and Ex 19:16a), אשר ("fire"; Ps. 97:3a and Ex 19:18a), הר ("mountain"; Ps 97:5a and Ex 19:16a), כבד ("to be weighty"; Ps 97:6b and Ex 19:16a).

23 Cf. further כהנים (Ps 99:6a and Ex 19:22a), קרא V ענה V (Ps 99:6c and Ex 19:20b), ("to answer"; Ps 99:6c.8a and Ex 19:19b).

24 The wisdom flavour of the pericope reminds of Pss 92:6-8.13-16 and 94:8-15; note ישרי לב ("the upright in heart") in 94:15b and 97:11b (†).

25 See Van der Lugt, Cantos III, 85-86.

26 For this reading, see Van der Lugt, Cantos III, 79; MT reads: “you lovers of YHWH hate evil." 
a symmetric relationship: 97:1-6, 7-12 | 99:1-5, 6-9 > a.b | b'.a'. This symmetric pattern enhances the pivotal position of Ps 98 within Sub-cycle II.

c Psalm 98 in the centre

Notwithstanding the conspicuous similarities between Pss 96 and 98, ${ }^{27}$ Ps 98 stands out in Sub-cycle II not only on the basis of its pivotal position in the context of the five psalms that Sub-cycle II is composed of, but also on the basis of its singular content.

Dieser Psalm konstatiert, daß das in Ps 96 angekündigte Kommen JHWHs zur weltweiten und endgültigen Durchsetzung seiner Weltordnung bereits begonnen hat - und zwar mit dem 'neuen' Exodus Israels aus dem Exil, wie der Psalm mit Anspielungen auf Deuterojesaja sagt. ${ }^{28}$

In 96:2b the psalmist calls (on all the earth) to proclaim God's salvation (בשרו מיום ליום ישועתו), while according to 98:3c-d the whole earth sees God's salvation (ראו כל אפסי ארץ \ת ישועת אלהינום). In 96:3 the psalmist calls on (all the

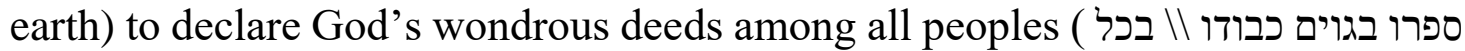

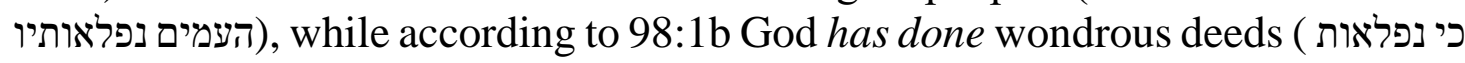
עשה (ע) Ps 98 is the apex of Sub-cycle II because it most explicitly makes it clear why songs of praise are appropriate: זכר חסדו ואמונתו \"לבית ישראל ל"he has remembered his steadfast love and his faithfulness // for the house of Israel"; 98:3a-b). This line sings the praises of Israel's salvation by God as an almost accomplished fact; note $3 \times \sqrt{ }$ ישע in vv. 1-3. ${ }^{29}$

My interpretation of 98:3 as the focal message of Sub-cycle II (and of the main cycle Pss 90-100) is supported by 98:4-6, the opening strophe of Canto II, where we find the "clearest indications of an actual enthronement, such as the

27 These similarities are generally recognized; see Jörg Jeremias, Das Königtum Gottes in den Psalmen. Israels Begegnung mit dem kanaanäischen Mythos in den Jahwe-KönigPsalmen (FRLANT 14; Göttingen: Vandenhoeck \& Ruprecht, 1987), 131; Howard, Psalms 93-100, 144-150; Zenger, "Theophanien," 432; Leene, "Coming," 211, speaks of "twin psalms"; Leuenberger, Konzeptionen, 150, speaks of "Zwillingspsalmen."

28 Zenger, "Theophanien," 425-426; see also Jeremias, Königtum, 135, Koenen, Jahwe wird kommen, 72, Zenger, "Weltenkönigtum," 162, and cf. Leene, "Coming," 223: "Psalm 98 unambiguously enters the field of history."

29 The phrase v. 3a-b does not occur elsewhere in the Hebrew Bible. The name ישראל is unique in the main cycle and is conspicuously framed by the geographical location (“Zion") mentioned in the preceding and following psalm (97:8a and 99:2a). For 98:3cd, see Isa 52:10c-d (for כל אפשי ארץ, see also Isa 45:22a; the expression does not occur elsewhere in the Hebrew Bible). For זרוע קדשו ("his holy arm") in 98:1d, see Isa 52:10a; for מלך אלהיך in Isa 52:7d. Isaiah 52:7-12 portrays God's festive entry from exile in his holy abode Zion. For the shared significant vocabulary as far as Ps 98 and Isa 52:7-10 is concerned, see also Jeremias, Königtum, 133. 
festive making of noise."30 In this respect, note the repetition of הריעו ("raise a shout"; vv. 4a.6b) זמרו ("sing praise"; vv. 4b.5a), the parallelism // וקול זמרה (") "the sound of a song" // "the sound of the horn"; vv. 5b and 6a respectively), and especially the accumulation of calls in the pivotal colon of the psalm, v. 4b (<12+1+12 cola), פצחו ורננו וזמרו ("break forth, shout joyfully, sing praise"). The repetition of $\sqrt{ }$ זמ in vv. 4-6 (3x) is all the more remarkable because זמר does not occur elsewhere in Sub-cycle II, but it does occur in the pivotal psalm of Sub-cycle I (Ps 92) and the central poem of the main cycle, Ps 95 (see Table V below). In addition, the strophe concludes with the unique wording המלך יהוה ("the king, YHWH"), once again expressing that God's kingship is an accomplished fact.

In this respect, it is also to be noted that within Sub-cycle II, it is only the pivotal Ps 98 and the concluding Ps 100 which have a heading, defining these psalms as מזמר (from $\sqrt{\text { מז }) \text { (ff. } § ~ B .2 . c ~ a b o v e ~ c o n c e r n i n g ~ t h e ~ h e a d i n g s ~ o f ~ P s s ~} 90$ and 92 within Sub-cycle I and note the heading of Ps 92 defining this psalm as מזמרור.

\section{PARALLEL FEATURES BETWEEN SUB-CYCLES I AND II}

The specific vocabulary supporting the alternating linear and concentric patterns within the Sub-cycles I and II (Pss 90-94 and 96-100 respectively) also reveals indications of a deliberately designed parallelism between these sub-cycles. There is a cluster of lexemes which occurs only in the A-psalms $(90,92,94)$ and the C-psalms $(96,98,100)$, while there is also a cluster of lexemes which occurs only in the B-psalms $(91,93)$ and the D-psalms $(97,99)$. Tables III and IV display the correspondences in question.

\section{Between the A- and the C-psalms}

Table III displays the correspondences between the A- and the C-psalms in terms of guide lexemes.

Table III

\begin{tabular}{|c|c|c|c|c|c|c|}
\hline & 90 & 92 & 94 & 96 & 98 & 100 \\
\hline (1) † אמונתו & & $3 \mathrm{~b}$ & & $13 \mathrm{~d}$ & & $5 c$ \\
\hline (2) בואل & $12 b$ & & & $8 b .13 a$ & $9 a$ & $2 \mathrm{~b} .4 \mathrm{a}$ \\
\hline † † גוי & & & $10 \mathrm{a}$ & $3 a .10 a$ & $2 b$ & \\
\hline (3) † דר ודר & $1 b$ & & & & & $5 c$ \\
\hline ل & & $2 b$ & & & $4 b .5 a+b$ & \\
\hline 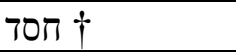 & $14 \mathrm{a}$ & $3 a$ & $18 \mathrm{~b}$ & & $3 \mathrm{a}$ & $5 b$ \\
\hline † חסד + אמונה & & 3 & & & $3 a$ & $5 b-c$ \\
\hline ( & & $14 \mathrm{~b}$ & & $8 b$ & & $4 \mathrm{~b}$ \\
\hline
\end{tabular}

30 Leene, "Coming," 213. 


\begin{tabular}{|c|c|c|c|c|c|c|}
\hline † טוב & & $2 a$ & & & & $5 a$ \\
\hline ل & $14 \mathrm{~b}$ & $5 b$ & & $12 b$ & $4 \mathrm{~b} .8 \mathrm{~d}$ & $2 b$ \\
\hline † שמחV + רנן V & $14 \mathrm{~b}$ & 5 & & $11-12$ & & $2 a-b$ \\
\hline † הארץ + שפט V & & & $2 a$ & $13 \mathrm{~b}$ & $9 \mathrm{~b}$ & \\
\hline heading & + & + & & & + & + \\
\hline
\end{tabular}

\section{Notes:}

(1) For אמן, see also 91:4c and 93:5a.

(2) For בואר, see also 95:6a.11b (Table V).

(3) " "generation and generation") is strategically positioned at exactly the "seams" of the main cycle, the first line of Ps 90 and the last line of Ps 100 (inclusion). See also the noun ("generation") in 95:10a (Table V)!

(4) For זמר ("to sing praise"), see also 95:2b (Table V)! It is noteworthy that the headings of Pss 92 and 98 also define these compositions as ממר (זמרור); for this definition, see also the heading of Ps 100 (מזמור לתודה).

(5) For רנן ("to shout [for joy]"), see also 95:1a (Table V).

The strategically positioned expression דר ודר ("generation and generation") in exactly the first poetic line of Ps 90 and the last poetic line of Ps 100 points to a symmetric relationship between the A- and the C-psalms: Pss 90.92.94 | 96.98.100 > W.X.Y | Y'.X'.W'.31 The nouns ("gladness") and

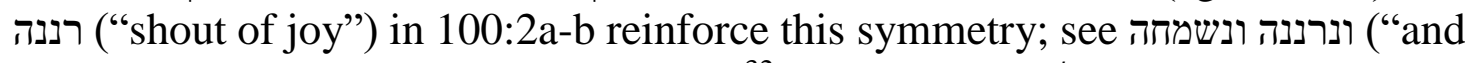
we will rejoice and be glad") in 90:14b. ${ }^{32}$ Additionally, זמר V ("to sing praise"), which highlights the pivotal compositions of the sub-cycles (Pss 92 and 98), smoothly fits the symmetric relationship between the A- and the C-psalms. As we have seen above, it is also Pss 92 and 98 which express the focal message of the sub-cycles. The symmetric relationship between the A- and the C-psalms is further supported by the conspicuous connections between Pss 94 and 92, on the one hand ( $\$ \mathrm{~B} 2 \mathrm{a})$, and Pss 96 and 98, on the other ( $\$ \mathrm{C} 2 \mathrm{a})$. The positioning of the headings which are only found in Pss 90 and 92, on the one hand, and 98 and 100, on the other, coincide with these symmetric aspects. The noun ("song") in the heading of Ps 92 fits the occurrence of שיר in Pss 96 and 98 (see Table II).

\section{Between the B- and the D-psalms}

Table IV displays the correspondences between the B- and the D-psalms in terms of guide lexemes.

31 The expression דר ודר does not occur elsewhere in the main cycle! For the relationship between Pss 90 and 100, see also Koenen, Jahwe wird kommen, 77-78.

32 For the combination of $\sqrt{ } \sqrt{ }$, 
Table IV

\begin{tabular}{|c|c|c|c|c|}
\hline & 91 & 93 & 97 & 99 \\
\hline (1) יהוה מלך & & $1 \mathrm{a}$ & $1 \mathrm{a}$ & $1 \mathrm{a}$ \\
\hline (2) † נכון כסאך / מכון כסאו & & $2 \mathrm{a}$ & $2 \mathrm{~b}$ & \\
\hline עדה ("precept”) עד & & $5 a$ & & $7 b$ \\
\hline ענה ("to answer") ענה & $15 \mathrm{a}$ & & & $6 c .8 \mathrm{a}$ \\
\hline י & $15 \mathrm{a}$ & & & $6 b+c$ \\
\hline † שמר & $11 b$ & & $10 \mathrm{~b}$ & $7 b$ \\
\hline
\end{tabular}

\section{Notes:}

(1) It is only in Pss 93, 97 and 99 that the proclamation יהוה מלך ("YHWH reigns") occurs at the very beginning of the psalm; see further Table II note (14).

(2) For the noun כסא ("throne"), see also 94:20a; for $\sqrt{ }$ (כ), see also 90:17a+b, 93:1c, 96:10b and 99:4b.

The symmetric positioning of some guide lexemes we found in Table III is in line with some unique lexical correspondences occurring in Pss 91 and 99, the second and second last compositions in the main cycle; see ענה $\sqrt{ }$ ("to answer") and ("to call"). The concluding strophe of Ps 91 (vv. 14-16), which is cast in the form of an oracle, is the climax of the composition. ${ }^{33}$ The opening colon of the pivotal line of this 3-line strophe, יקראני ואענהו ("he calls upon me and I answer him"; v. 15a) introduces the idea that God will save the supplicant. The historical references in Ps 99:6-9, speaking of the communication between God, on the one hand, and Moses, Aaron and Samuel, who called on the name of the LORD, on קראים אל the other, guarantee the trust of the supplicant expressed in Ps 91; note קרים ("the calling ones on YHWH and He answered them"; 99:6c), and cf. בקראי שמו ("among the ones who called on his Name"; 99:6b), אתה עניתם ("you answered them"; 99:8a). Subsequently, the symmetric design of the sub-cycles is reinforced by the lexical correspondences נכון כסאך ("your throne is established") / "מכון כסאו ("the foundation of his throne") occurring in Pss 93 and 97 respectively. ${ }^{34}$ In this context, it is also meaningful that according to $97: 1-6$ YHWH's revelation has a destructive effect on nature and on his enemies: "mountains melt away like wax" (v. 5a) and YHWH's fire "devours his foes all around" (v. 3). This motif fits the portrayal of the mythological, hostile forces in terms of natural threats which oppose YHWH's dominion we find in 93:3-4b.

\footnotetext{
33 About the ingenious poetic design of this strophe, see Van der Lugt, Cantos III, 3435.

34 The repetition of the colon אף 93:1c and 96:10b obviously does not fit the schematic overviews presented in Tables III and IV; the same holds for, among other things, נקם in 94:1a+b and 99:8c, for על כל אלהים in Pss 95:3b, 96:4b and 97:9c.
} 
The parallelism between the B- and the D-psalms is enhanced by a special phenomenon which connects Pss 97 and 99, on the one hand, and Pss 91 and 93, on the other; see the opening phrase "YHWH reigns" in Pss 97 and 99 (responsion on psalm level; Table II) and the expression "length of days" in the concluding lines of Pss 91 and 93 (responsion on psalm level; Table I).

\section{The thematic individuality of Psalms 90 and 100}

The symmetric relationship between Sub-cycles I and II is also revealed by the thematic individuality of Pss 90 and 100 in the context of their sub-cycles. Pss 91-94 are about the relationship between God and an individual believer. These psalms especially portray the trust the righteous individual may have in God's protection. From this point of view, Ps 90 stands out as opening composition, because it is a communal lament and not about God's relationship with an individual believer.

Pss 96-99 speak of YHWH as King and Judge over peoples/nations; see גוים ("peoples") in 96:3b.5a.7a.10c.13d, 97:6b, 98:9d, 99:1a.2b and עמים ("nations") in 96:3a.10a, 98,2b. ${ }^{35}$ The royal authority of YHWH has to be proclaimed among all peoples (אמרו בגוים יהוה מלך; 96:10a); they are aware of God's glory and might (96:3.7, 97:6b, 98:2, 99:1a). In this context, Ps 100 stands out as concluding composition because it is not about God's royal authority over peoples but about the "acknowledgment" (דעו; v. 3a) of the "whole earth" (כל כל הארץ; v. 1a) of the unique relationship God has with the people of Israel (v. 3) and of his everlasting faithfulness to them (v. 5). Psalm 100 is a hymn on God's enduring loyalty to Israel and lacks the universal outlook in connection with his royal authority as it is phrased in Pss 96-99. ${ }^{36}$

\footnotetext{
35 The גוים spoken about in 94:10a occur in the context of the portrayal of God's wisdom and not of his royal authority. In Pss 94:5a.8a.14a, 95:7b.10b, and 100:3c עם refers to the people of Israel.

36 At variance with Zenger who (following Lohfink) maintains that 100:3 "die sogenannte Bundesformel, die traditionell gerade die Sonderstellung Israels gegenüber den Völkern ausdrückt, nun auch den Völkern als Bekenntnis über ihr Verhältnis zu JHWH in den Mund legt" (Hossfeld and Zenger, Psalmen 51-100, 710-711); similarly Zenger, "Theophanien," 427. On the basis of this interpretation of 100:3, with regard to the meaning of Ps 100 in its literary context, Zenger maintains: "Liest man Ps 93-100 als fortlaufenden Zusammenhang, treten die Völker mehr und mehr in das Zentrum des Geschehens bzw. in die Nähe Israels und seines Gottes" (Hossfeld and Zenger, Psalmen 51-100, 712). For a criticism of Zenger's interpretation of 100:3, see also Theodor Lescow, "Die literarische Struktur des Psalms 100," BN 110 (2001): 38-41 (41), who maintains: "Die schöpfungstheologische Aussage Ps 100:3 ist [...] erwählungstheologisch zu interpretieren."
} 


\section{E THE BRIDGING FUNCTION OF PSALM 95}

\section{Guide lexemes}

Within the main cycle consisting of $\mathbf{1 1}$ psalms (Pss 90-100), the $\mathbf{1 1}$ lines of Ps 95 represent the pivotal composition. Ps 95 is flanked by groups of five psalms on both sides, Pss 90-94 and 96-100. Poems with eleven or a multiple of eleven lines do not occur elsewhere in the main cycle. ${ }^{37}$ The eleven letters of the pivotal colon of the psalm, כי הוא אלהינו ("yes, He is our God"; vv. 1-6.7a.7b-11 > 12+1+12 cola and $43+3+43$ words) once more highlight the pivotal position of Ps 95 in the main cycle.

Before pointing out the pivotal position of Ps 95 in terms of content, I will display this position in terms of unique recurrent items of vocabulary which act as guide lexemes. From this perspective, Ps 95 has specific relationships with, on the one hand, Pss 90, 92 and 94, and, on the other, Pss 96, 98 and 100.

Table V

\begin{tabular}{|c|c|c|c|c|c|c|c|}
\hline & 90 & 92 & 94 & 95 & 96 & 98 & 100 \\
\hline $\begin{array}{l}\text { ("people" = } \\
\text { Israel) † }\end{array}$ & & & $\begin{array}{l}5 a .8 a . \\
14 a\end{array}$ & $7 b .10 b$ & & & $3 \mathrm{c}$ \\
\hline ( & & & & $7 b$ & & & $3 b$ \\
\hline † † " ("anger ") אף & 7a.11a & & & $11 \mathrm{a}$ & & & \\
\hline (1) + בואר & $12 \mathrm{~b}$ & & & $6 a .11 b$ & $8 b .13 a+b$ & $9 a$ & $2 \mathrm{~b} .4 \mathrm{a}$ \\
\hline (2) † בתודה & & & & $2 \mathrm{a}$ & & & $4 a$ \\
\hline לור † דור & $1 \mathrm{~b}$ & & & $10 \mathrm{a}$ & & & $5 c$ \\
\hline (3) ז זמר & & $2 b$ & & $2 b$ & & $4 b .5 a+b$ & \\
\hline 列 & & & $9 \mathrm{~b} .20 \mathrm{~b}$ & $5 b$ & & & \\
\hline † מרעית & & & & $7 b$ & & & $3 c$ \\
\hline (4) † עשנן & & & & $6 \mathrm{~b}$ & & & $3 b$ \\
\hline † ("doing” פעל (") & $16 \mathrm{a}$ & $5 a$ & & $9 b$ & & & \\
\hline (ל + צען & & & & $7 \mathrm{c}$ & & & $3 c$ \\
\hline † † צור & & $16 \mathrm{~b}$ & $22 b$ & $1 \mathrm{~b}$ & & & \\
\hline † רוע & & & & $1 \mathrm{~b} .2 \mathrm{~b}$ & & $4 a .6 b$ & $1 \mathrm{a}$ \\
\hline רנן & $14 \mathrm{~b}$ & $5 b$ & & $1 \mathrm{a}$ & $12 b$ & $4 \mathrm{~b} .8 \mathrm{~d}$ & \\
\hline (5) † שנה & $\begin{array}{l}4 a \cdot 9-10 \\
(4 \times) \cdot 15 b\end{array}$ & & & $10 \mathrm{a}$ & & & \\
\hline
\end{tabular}

\section{Notes:}

(1) Like the second strophe of Ps 100 (vv. 4-5), the second canto of Ps 95 (vv. 6-11) באו ("enter").

(2) ידה ("to praise") also occurs in 92:2a, 97:12b, 99:3a, 100:4c.

37 For the 11 lines of Ps 95, see Van der Lugt, Cantos III, 62-70, and for the structuring function and symbolic meaning of the number 11, see $\S \mathrm{F}$ below.

38 Within Ps 100 this call constitutes a responsion with ("enter") in v. 2b. 
(3) Note: זמר ("to sing praise") not only features in the pivotal psalms of Sub-cycles I and II (Table III), but also highlights Ps 95, the pivotal composition of the main cycle.

(4) Cf. also (הוא עשנו עשהו ("he made us") in 100:3b with ("ande it") in 95:5a.

(5) Additionally, in both Pss 90 and 95 the noun ("year") occurs in combination

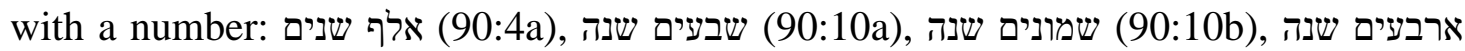

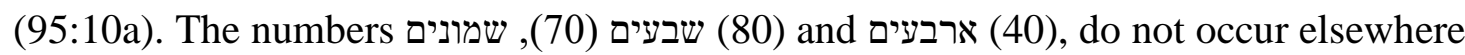
in the Psalter; for אלף ("thousand”), see Pss. 68:18, 84:11, 105:8, 119:72.

In terms of guide lexemes, the noun ("generation") supports the pivotal position of Ps 95 within the main cycle; the noun exclusively occurs in the opening, middle and concluding psalm (90:1b, 95:10a, 100:5c). In terms of guide lexemes, there is only a loose relationship between Pss 100 and $99,{ }^{39}$ however, Table V shows that from this perspective Ps 100 clearly refers to Pss 98, 96 and $95 .{ }^{40}$ Moreover, different from the vocabulary of Pss 97 and 99, it is primarily the vocabulary of Pss 95, 96, 98 and 100 which displays conspicuous correspondences with some poetic lines in Isa 40-55. In this respect, see שירו ראו כל אפשי ארץ \ורו את ישועת אלהינו in Pss 96:1a, 98:1a and Isa 42:10a ליהוה שיר חדש in Ps 98:3c-d and Isa 52:10c-d. Compare further Pss 95:7b-c and 100:3c with Isa

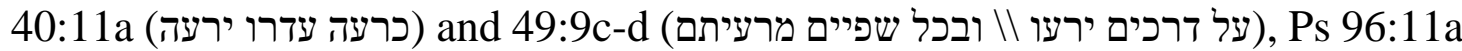

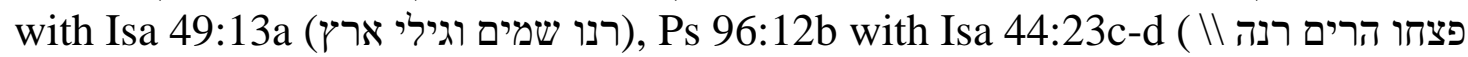
(יער וכל עץ בו), Ps 98:1d with Isa 52:10a (זרוע קדשו), Pss 98:4a and 100:1a with Isa 44,23b (הריעו תחתיות ארץ), Ps 98:8b with Isa 44:23c (פצחו הרים רנה) and 49:13b (יפצחו הרים רנה).

\section{Rhetorical design and content}

Ps 95 does not only stand out in the cycle Pss 90-100 on the basis of its central position in a cycle of $\mathbf{1 1}$ psalms, the $\mathbf{1 1}$ poetic lines the poem consists of, and its guide lexemes (Table V), but also because of its rhetorical structure and specific content. From a thematic perspective, Ps 95 displays specific correspondences with Pss 90 and 100, the opening and concluding psalms of the main cycle. ${ }^{42}$

\footnotetext{
39 Van der Lugt, Cantos III, 104-105.

40 Similarly Zenger, “Theophanien,” 431-432; cf. Koenen, Jahwe wird kommen, 7677.

41 For the relationship of Pss 96 and 98 with Isa 40-55, see also Jeremias, Königtum, 121-136.

42 Leuenberger, Konzeptionen, 130.156-57.171, finds a concentric framework in the cycle Pss 93-100: 93.95.96 | 97:1-9* | 98.99.100 > A.B.C | X | C.'B.'A'; Ps 94 is "Nachtrag" (145-147). At the same time, Leuenberger, Konzeptionen, 171-172, argues "daß die Komposition 93-100* gar nie selbständig für sich existiert hat, sondern von vornherein an 90-92 ... angeschlossen hat." The expression דר ודר frames the "Doppelkomposition" Pss 90-92 and 93-100; Leuenberger, Konzeptionen, 170. O. Palmer Robertson, The Flow of the Psalms. Discovering their Structure and Theology
} 


\section{Van der Lugt, "His Faithfulness," OTE 32/2 (2019): 606-635}

\section{a Specific connections between Psalms 95 and 90}

As is the case in Ps 90 (see especially Cantos II and III, vv. 7-12 and 13-17), in the opening strophes of the cantos of Ps 95 (vv. 1-2 and 6-7) the psalmist, as a member of the community, speaks in the first person plural. Within Sub-cycle I, this phenomenon is only represented by אלהינו ("our God") in 92:14b (בחצרות (אלהינו) and 94:23c (יהוה אלהינו); see Table I. The relationship between Pss 95 and 90 is corroborated by the noun ("anger") which occurs only in the psalms concerned. In Ps 95 the noun אף is used in the context of the portrayal of Israel's disobedience during the period of the sojourn of forty years in the wilderness (vv. 8-11); note אשר נשבעתי באפי ("so, I swore in my anger"; v. 11a). In the second canto of Ps 90 the exiles complain that they are consumed by YHWH's "anger" (v. 7a; see also v. 11a). Within the main cycle the portrayal of the people's disobedience in the wilderness in Ps 95 is an illustration of Israel's stubborn rebelliousness in general and explains God's wrath and anger portrayed in Ps 90. Ps 95 locates Israel's rebellious behaviour in the "heart" (לבב; vv. 8a.10b). In view of this observation, the prayer for a "wise heart" (לבב חכמה; v. 12b) at the end of the second canto of Ps 90 is very appropriate. In this light we may safely assume a deliberately designed relationship between the forty years of Israel's stay in the wilderness (95:10a) and the maximum duration of life of a mortal human, eighty years $(2 \times 40 ; 90: 10 \mathrm{~b})$. Finally, the reproach of Israel's rebellious behaviour גם ראו פעלי ("though they had seen my work"; 95:9b) explicitly harks back to the petition יראה על עבדיך פעלך ("let see your work to your servants"; 90:16a). ${ }^{43}$ The reproach reveals in a straightforward way that the lament expressed in Ps 90 is not appropriate. Simultaneously, in the light of this harsh reproach, the summons to praise the LORD (95:1-2.6) and the confession "we are the people of his pasture // and the flock of his hand"; 95:7b-c) is all the more remarkable. ${ }^{44}$

The connections between Ps 95, on the one hand, and Pss 96, 98 and 100, on the other, in terms of guide lexemes (Table V) are corroborated by the rhetorical design of the psalms concerned. As is the case in Pss 96, 98 and 100 (and different from Pss 97 and 99; see $\S$ C2a above), in Ps 95 the summons to honour the LORD marks the beginnings of the cantos (vv. 1-2 and 6-7). And, as is the case in Pss

(Phillipsburg, NJ: P\&R Publishing, 2015), 157-160, considers Ps 96 the centre of Pss 92-100 (<4+1+4 psalms).

43 Cf. the references occurring in $92: 2-5$ and $94: 1-4$ to the prayer $90: 13-17$ pointed out in $\S$ B2a. That is to say, the supplication 90:13-17 plays a crucial role in the framework of the main cycle. According to Koenen, Jahwe wird kommen, 57-58, Ps 90:13-17 "dürften von dem Kompositor stammen, der Ps 90-92 zusammengestellt hat"; the pericope is a "Fortschreibung." Hossfeld and Zenger, Psalmen 51-100, 608, speak of a "gezielte Fortschreibung."

44 For the connections between Pss 95 and 90, see also Krüger "Psalm 90," 215. 
96, 98 and 100, this summons is followed by the reason why a tribute is appropriate, introduced by (95:3-5.7). In this respect, cf. especially 95:3-5 with 96:4-6: for YHWH is a great God [...]!; note the correspondence between the lines 95:3 and 96:4 in their entirety. In the second canto of Ps 95 this reason is expressed in the same strophe as the summons to pay tribute: כי הוא אלהינו (for He is our God"; v. 7a).

In addition, Pss 95 and 100 display specific correspondences. The second canto of Ps 95 (vv. 6-11; note vv. 6-7) does not only refer to Ps 90 (the opening poem of the main cycle; see above), but has a unique relationship with Ps 100 (the concluding poem of the main cycle), as well; note the opening strophe 100:13. In both cases the psalmist speaks as a member of the community; note אנחנו ("we"; 95:7b and 100:3b). Within Sub-cycle II this phenomenon is only represented by אלהינו ("ישועה אלהינו) ("our God") in 98:3d 99:5a.8a.9a+c ( יהוה אלהינו psalmist calls on his fellow believers to come before the LORD, in Ps 100 he calls on the whole world: באו לפניו (100:2b). In both cases he confesses that the LORD is the Creator of Israel (עשנו; "he made us"; 95:6b and $100: 3 \mathrm{~b}$ ), and speaks of the community as the flock of God's pasture (95:7b-c and 100:3c). Additionally, the strophes 95:6-7 and 100:1-3 consist of two tricola; within Ps 95, the strophe vv. 6-7 is the only strophe which is composed of tricola throughout. For the specific relationship between Pss 95 and 100, see also the strategic positioning of $\sqrt{ }$ in the opening lines of the psalms (95:1a and 100:2b), the strategic positioning of the imperative plural באו at the very beginning of the second canto of Ps 95 (v. 6a) and the second strophe of Ps 100 (v. $4 \mathrm{a}){ }^{45}$

\section{c “To sing” in the pivotal poems of Psalms 90-100}

The pivotal position of Ps 95 within the main cycle of psalms is also highlighted by זמר ("to sing praise"; see Table V). This root only features in Pss 92 (the pivotal poem in Sub-cycle I), 95 (the pivotal poem in the main cycle Pss 90-100), and 98 (the pivotal poem in Sub-cycle II; note the accumulation of this root in vv. 4-6); see also רנן ("to shout [for joy]") in Table V. This phenomenon indicates that the principal purpose of the main cycle is to sing the praises of the LORD.

\section{F NUMERICAL FEATURES}

The deliberately designed structure of the cycle Pss 90-100 also manifests itself through the use of various conspicuous numerical features. The structuring function and meaning of the number 7 need no explanation. Following the

45 Cf. further the noun עם ("nation") in 95:7b.10b, 100:3c, and כלי הוא אלהינו / דעו כי יהוה in 95:7a and 100:3a respectively. For the relationship between Pss 95 and 100, see also Tate, Psalms 51-100, 535-536, Howard, Psalms 93-100, 138-141. 
investigations by Labuschagne, I assume that the numbers 26 and 17 are also important because in gematria they represent the numerical value of the divine name YHWH: $\mathrm{Y}+\mathrm{H}+\mathrm{W}+\mathrm{H}>10+5+6+5=26$ and $1(0)+5+6+5=17$. The number 11 (and its multiples) turns up conspicuously in alphabetic acrostics because, among other things, the Hebrew alphabet has $22(=2 \times 11)$ letters. Taking into account this fact, it is reasonable to assume that eleven symbolizes the idea of "fulfilment, completeness." 46

The cycle Pss 90-100 consists of 11 individual compositions. This is a structuring phenomenon which is regularly to be found in the Psalter to mark coherent cycles of poems. ${ }^{47}$ In addition, within this main cycle the central composition Ps 95 stands due to its 11 poetic lines. ${ }^{48}$ For the total number of 140 poetic lines of the main cycle, see below.

Taking into account the structural function of the numbers seven and eleven, in my opinion, it is not by chance that Pss 90-94 (Sub-cycle I) have exactly $77(=7 \times \mathbf{1 1})$ poetic lines in total $(<18+16+15+5+23$ lines in the consecutive psalms). ${ }^{49}$ It noteworthy too, that the break between Pss 92 and 93 divides Sub-cycle I into $49(=7 \times 7)$ and $28(=4 \times 7)$ poetic lines $(49<18+16+15$

46 For a more elaborate explanation of the meaning of the numbers in question, see Pieter van der Lugt, Cantos and Strophes in Biblical Hebrew Poetry: With Special Reference to the First Book of the Psalter (OTS 53; Leiden: Brill, 2006), 84-87, and Cantos III, 6-8. For the number 11, see also the appendix

47 For cycles of 11 psalms, see also Pss 19-29, 32-41 (a cycle characterized by the repeated blessing אשרי (2); Ps 40 represents two poems, 40:2-13 and 40:14-18), Pss 73-83 (a לבני אסף-cycle), Pss 107-117; for the time being, cf. Casper J. Labuschagne, "Significant Sub-Groups in the Book of Psalms: A New Approach to the Compositional Structure of the Psalter," in The Composition of the Book of Psalms (ed. Erich Zenger; BETL 238; Leuven: Peeters, 2010), 623-634. In this respect, it is noteworthy that, as Pss 90-100 feature at the beginning of Book IV, the cycles Pss 73-83 and 107-117 feature at the beginning of Books III and V respectively. I realize that my identification of Pss 1929 as an individual cycle runs counter to the general assumption that Pss 15-24 represent a coherent unit of psalms. Both the first and the second cycle of poems in the Book of Job (chs 4-14 and 15-26 respectively) also consist of 11 relatively individual compositions; see Pieter van der Lugt, Rhetorical Criticism and the Poetry of the Book of Job (OTS 32; Leiden: Brill, 1995), 504-519.533. In addition, both cycles have 270 poetic lines, while Job 9, the pivotal poem of the first cycle, is composed of 11.12.11 poetic lines (cf. Ps 95 with 11 poetic lines).

48 Cf. the $\mathbf{1 1}$ poetic lines of Ps 46 and the 77 poetic lines of Ps $78(<\mathbf{1 1}+\mathbf{3 3}+\mathbf{3 3}$ lines $)$ as the central poems within the cycles Pss 42-49 (a לבני קרח-cycle; 7 poems) and 73-83 respectively; the poetic lines of Ps 46 coincide with the Masoretic verses, Ps $78: 4,5,8,20,38$ have two lines of poetry.

49 For the total number of lines of Pss 90-94, cf. the 77 poetic lines of Ps 78 . In most cases, the lines of Pss 90-94 coincide with the Masoretic verses. Pss 90:10, 92:9-10, 93:1-2 have two lines; I take 92:9-10a as a bicolon and 93:1c-2 as a tricolon. 
lines and $28<5+23$ ). In this context, it is probably not by chance either that the 7 words of the hymnic poetic line 92:6, מה גדלו מעשיך יהוה \מאד עמקו מחשבתיך ("how great are your works, YHWH // very profound are your thoughts"), represent the middle line of this sub-cycle $(<38+1+38$ lines); note also יהוה as the pivotal word of the line $(<3+1+3$ words). As already pointed out above, the middle poem of Sub-cycle I (Ps 92) stands out on the basis of its unambiguous hymnic flavour.

The deliberately designed coherence of Pss 96-100 (Sub-cycle II) is corroborated by the number 26. The sub-cycle has exactly $52(=2 \times \mathbf{2 6})$ lines of poetry $(<14+12+12+10+4$ lines in the consecutive psalms $) .{ }^{50}$ It is also to be noted that the break between Pss 97 and 98 divides the sub-cycle into $\mathbf{2 6}$ and $\mathbf{2 6}$ poetic lines (Pss 96+97 have 14+12 lines and Pss 98-100 have 12+10+4 lines). ${ }^{51}$

The main cycle, Pss $90-100$, has exactly $140(=20 \times 7)$ lines of poetry: Pss 90-94+95+96-100 have $\mathbf{7 7 + 1 1 + 5 2}=\mathbf{1 4 0}$ lines. I consider the numerical approach of important relevance in the context of the investigation into the boundaries of the main cycle and its sub-cycles. Because the numerical features described above can hardly be perceived by only unsuspectingly memorizing the texts concerned, we have to assume a written form which from the outset has been at the root of the main cycle.

In Sub-cycle I the divine name יהוה occurs 24 times; in addition, Ps 94 has 2 times the shortened form יהוה/יה That is to say, in Pss 90-94 the divine name occurs 26 times in total: $1 \times$ in Ps 90, $2 \times$ in Ps 91, 7x in Ps 92 (cf. the 7 words of v. 6), 5x in Ps 93, and 11× in Ps 94. In Sub-cycle II, the divine name יהוה occurs 34 times (=2×17): 11× in Ps 96 (cf. Ps 94), 6x in Ps 97, 6× in Ps 98, 7× in Ps 99, and $4 \times$ in Ps 100 . That is to say, within the main cycle Pss 90-100 the divine name יהוה/יה occurs 26+3+34=63 times in total $(63=9 \times 7)$.

50 Cf. the $\mathbf{5 2}$ poetic lines of Ps 18 at the end of the cycle Pss 9-18 (this cycle has $\mathbf{1 5 6}$ $=6 \times 26$ poetic lines) and Ps 89 at the end of Book III of the Psalter; for the poetic lines of these psalms, see Van der Lugt, Cantos I, 204-205, and Pieter van der Lugt, Cantos and Strophes in Biblical Hebrew Poetry II: Psalms 42-89 (OTS 57; Leiden: Brill, 2010), 462-463 respectively. I realize that my identification of Pss 9-18 as an individual cycle runs counter to the general assumption that Pss 15-24 represent a coherent unit of psalms. In most cases, the poetic lines of Pss 96-100 coincide with the Masoretic verses; Pss 96:13, 98:1,3,9, 99:4 have two poetic lines, while Ps 100:1-2 is a tricolon.

51 On the basis of this break in Sub-cycle II in terms of significant poetic lines (26 and 26 lines) and the similar break in Sub-cycle II (49 and 28 lines), the symmetric relationship between the sub-cycles once again comes to light: Pss 90-92.93-94 | 9697.98-100 > $3.2 \mid 2.3$ psalms. 
Table VI

\begin{tabular}{|c|c|c|c|}
\hline $90-94$ & 95 & $96-100$ & $90-100$ \\
\hline 5 psalms & 1 psalm & 5 psalms & 11 psalms \\
\hline 77 lines & 11 line & 52 lines & 140 poetic lines \\
\hline יהוה/יה ×26 & יהוה 3× & יהוה ×34 & יהוה/יה ×63 \\
\hline
\end{tabular}

\section{G MEANING IN LITERARY SETTING}

My investigations with regard to the coherence of the cycle Pss 90-100 lead me to conclude that the redactor who was responsible for this main cycle within Book IV of the Psalter has used poems which stem from different sources, like wisdom traditions, liturgical and cultic performances. Notwithstanding the incongruity of these traditions, the skeleton of his overall cycle is well-thought-out. Moreover, the redactor has introduced a dramatic progression in it. His cycle opens with a communal lament on the hopeless situation of the people of Israel because of God's anger (Ps 90) and concludes with a summons to give thanks to the LORD because of his everlasting faithfulness (Ps 100). After all, from a thematic point of view, the coherence of the cycle Pss 90-100 cannot be compared to that of e.g. Pss 120-134, a cycle which is obviously "aus einem Guß." 52

Additionally, the possibility is not to be excluded that in some cases the redactor has adapted the poems at his disposal to make them fit for his overall cycle. Maybe, in an ingenious way (among other things by linking up with the שוב in v. 3a+b), 90:13-17 has been added by him to make 90:1-12 fit the design of the main cycle and its reasoning. The supplication 90:13-17, plays a crucial role in the framework of this cycle; note the references occurring in 92:2-5, 94:14 and 100:2a-b. ${ }^{53}$ Botha has argued that Ps 91 "was transformed to become part of a canonical corpus." ${ }^{54} \mathrm{Ps} 97$, as an anthology of quotations from other biblical poems, ${ }^{55}$ suggests that the psalm is composed in order to fill a structural lacuna in the main cycle. This is almost generally assumed for Ps 100: "Ps 100 ist wohl für seinen Kontext geschrieben worden. [...] Der Psalm hat seinen Sitz deswegen nicht im Kult, sondern in der Literatur." ${ }^{66}$ The above observations imply that

52 For the coherence and design of the cycle Pss 120-134, see Van der Lugt, Cantos III, 422-440.

53 For the ingenious combination of various poetic units into a perfect new composition, see Ps 108. This psalm is the contraction of Pss 57:8-12 and 60:7-14; Van der Lugt, Cantos III, 205-210.

54 Botha, "Psalm 91," 274; according to Botha, this canonical corpus includes Pss 9092.

55 Jeremias, Königtum, 142.

56 Koenen, Jahwe wird kommen, 76, Lescow, "Die literarische Struktur," 40; see also Van der Lugt, Cantos III, 105. 
what holds for Ps 100 is true of the cycle in its entirety, too: the cycle Pss 90-100 is a literary construction. ${ }^{57}$

On the basis of the cycle itself, it is impossible to determine the specific situation from which it has emerged, its "Sitz im Leben." The references to Isa $40-55 / 66$ point to a post-exilic compilation. However, taking into account the literary setting of Pss 90-100, the specific message of this opening cycle of Book IV of the Psalter is pretty clear. The cycle has conspicuous relationships with Ps 89, the concluding composition of Book III. In the first place, there are remarkable correspondences between Pss 90 and 89. The opening canticle of Ps 89 (vv. 2-5) is demarcated by the expression לדר ודר (vv. 2b.5b); line of Ps 90 winds up with בדר ודר (v. 1b). Ps 90:3-6 reminds of the theme of man's transitory existence touched upon in 89:48-49; note בני אדם (human beings") in 90:3b and 89:48b. In both cases, the concluding (sub-) canto, 90:1317 and 89:47-52, is a prayer for deliverance. In terms of significant vocabulary, these concluding units stand out by עבדיך ("your servants"; 89:51a and 90:13b.16a) אדני ("Lord"; 89:50a.51a and 90:17b); see further, among other things, אור פניך / מאור פניך (89:16b and 90:8b respectively). That is to say, Ps 90 especially links up with and elaborates on the prayer for deliverance phrased in the concluding sub-canto of Ps 89 (concatenation and enjambment). However, from its very outset Ps 90 indicates what the answer will be: "O Lord, You have been our haven // from generation to generation" (90:1). Secondly, there are remarkable correspondences between the Pss 96-100 (Sub-cycle II) and Ps 89. This relationship is especially based on the guide lexeme ("faithfulness"; Table III). As we have seen, this noun stands out in Sub-cycle II because אמונתו ("his faithfulness") is strategically positioned at the very end of Pss 96 and 100 (96:13d and 100:5c), while the noun also occurs in the pivotal poems of the subcycles (92:3b and 98:3a). Taking into account the structural function of אמונה in Pss 90-100, its structural function in Ps 89 is hardly by chance. Ps 89 is larded with this noun. The expression ("your faithfulness") demarcates the boundaries of the psalm (vv. 2b.3b and 50b); it also demarcates the unit vv. 6-9 (vv. 6b.9c); for ("my faithfulness"), see 89:25a.34b. ${ }^{59}$ From a numerical point of view, the relationship between Pss 96-100 and Ps 89 is underlined by the 52 poetic lines Pss 96-100 as well as Ps 89 consist of (89:20 has two lines of poetry).

57 Zenger, "Theophanien," 438, calls Pss 93-100 in its final form and as "Fortschreibung" of Pss 2-89 a "theologisches 'Lesebuch"” (not meant for reciting in a liturgical context).

58 For the rhetorical design of Ps 89, see Van der Lugt, Cantos II, 462-484.

59 In this respect, it says a lot that, with the exception of $88: 12 \mathrm{~b}$, the noun not occur elsewhere in Books III and IV. With the exception of 89:6.9 and 96:13c-d, in Pss 88-89 as well as in Pss 90-100, אמונה is always flanked by ('steadfast love'). 
Taking into account the lament about the absence of the former tokens of God's ("steadfast love") and ("faithfulness") phrased in 89:50 and the links between this lament and Ps 90, we may safely assume that the song of praise on YHWH's המונה in the final line of Ps 100 functions as a deliberate counterpoint. Within the literary setting of the concluding psalm of Book III and the opening cycle of Book IV, the phrase "yes, YHWH is good // his steadfast love is for ever // and from generation to generation his faithfulness" (100:5), is the deliberately designed concluding statement of Pss 90-100. ${ }^{60}$ Subsequently, as already pointed out above $(\S \mathrm{C} 2 \mathrm{c})$, this final statement is based on the reference to the deliverance from exile phrased in 98:3a-b: זכר חסדו ואמונתו \לבית ישראל ("he has remembered his steadfast love and his faithfulness // for the house of Israel"). Taking into account the relationship between 100:3 and 89:50, it also comes to light that 98:3a-b is the deliberately designed answer to the prayers phrased in 89:48.51 marked by the opening imperative זכר ("remember"); see especially 89:51: ("remember, O Lord, the disgrace of your servants // [...]"). ${ }^{61}$

\section{H CONCLUSION}

Psalms 93-100 are almost generally considered an individual cycle of "YHWHKing-psalms." Here it is argued that Ps 100 is the concluding composition of a cycle consisting of eleven psalms which starts at Ps 90. This major cycle is composed of two sub-cycles of five psalms, Pss 90-94 and Pss 96-100, which frame a pivotal composition of eleven poetic lines, Ps 95. The rhetorical design of the main cycle is determined by content and several formal features. The latter rhetorical means include the use of meaningful numbers like 7, 11, 26, and the strategic positioning of unique significant vocabulary as guide lexemes.

The main cycle has $140(20 \times 7)$ poetic lines, while Sub-cycle I has $\mathbf{7 7}$ $(\mathbf{1 1} \times \mathbf{7})$ lines and Sub-cycle II $52(2 \times \mathbf{2 6})$ lines. The overall design of Pss 90-100 is supported by the strategic positioning of guide lexemes. In addition, guide lexemes determine the alternating and concentric relationships between distant

60 Cf. Tate, Psalms 51-100, 536; in this respect, Tate points to "the sevenfold use of 'faithfulness' in Ps 89 and the sevenfold summons to praise Yahweh for his enduring 'faithfulness' in Ps 100." At variance with Schnocks, Vergänglichkeit, 261-263, who argues that Pss 90-92 and 102-103 represent the "primäre Fortschreibung des messianischen Psalters" Pss 2-89; Pss 90-92 are supposed to provide various solutions to the problem of humankinds transitory existence (similarly Dahmen, "Gepriesen," 21 22). Cf. Ballhorn, Telos, 74-81, who argues that it is Ps 90 which is to be taken as answering the prayer marking the end of Ps 89.

61 Similarly Bernard Gosse, "Le parallélisme synonymique hsd 'mwnh, le Ps 89 et les réponses du quatrième livre du Psautier, Ps 90-106," ZAW 122 (2010): 185-198 (188189)! For the helpless petitions for deliverance phrased in vv. 48 and 51 as the quintessential thought of Ps 89, see Van der Lugt, Cantos II, 481. As a verb זכר V זכ ש not occur elsewhere in Pss 89-100; for the noun זכר ('memory'), see 97:12b. 
psalms. In the case a conspicuous application of numerical features coincides with (strategically positioned) guide lexemes, I assume we enter the domain of certainty as far as the design of Pss $90-100$ is concerned. Semantic observations support the former approaches.

The borders of the main cycle are marked by the expression דר ודר ("generation and generation"; Pss 90:1 and 100:5). The pivotal psalms of the subcycles (Pss 92 and 98) stand out in their context by the occurrence of זמר V (to sing praise"; 92:2b and 3 times in 98:4-5). Remarkably enough, the latter phenomenon coincides with the definition of Pss 92 and 98 as מזמור, occurring in the headings of these psalms. זמר ז not only highlights the pivotal psalms of the sub-cycles, but also the pivotal composition of the cycle as a whole; see Ps 95:2b.

Within Sub-cycle II, Ps 98 most explicitly expresses the reason why a song of praise is appropriate: the LORD has remembered "his steadfast love" (חסדו) and "his faithfulness (אמונתו) for the house of Israel (98:3a-b). This motif refers to the deliverance of the Judean community from their exile in Babylon. Within the literary setting of Ps 89 (the concluding psalm of Book III) and Pss 90-100 (the opening cycle of Book IV) this motif and the song of praise on YHWH's and in Ps 100:5 function as the deliberately designed counterpoint to the lament on the absence of God's faithfulness, which characterizes the concluding unit of Ps 89 (vv. 47-52).

Table VII

\begin{tabular}{|c|c|c|c|c|c|c|c|c|c|c|}
\hline 90 & 91 & 92 & 93 & 94 & 95 & 96 & 97 & 98 & 99 & 100 \\
\hline תפלה & & מזמור & & & & & & מזמור & & מזמור \\
\hline דר ודר & & & מלך יהוה & & & שיר & מלך & שיר & מלך & \\
\hline & & זמרل & & & זמרل & & & זמרل & & \\
\hline & & & & & דור & & & & & \\
\hline & אימים ארך & & אימים & & & & & & & דר ודר \\
\hline
\end{tabular}




\section{BIBLIOGRAPHY}

Ballhorn, Egbert. Zum Telos des Psalters. Der Textzusammenhang des Vierten und Fünften Psalmenbuches (Ps 90-150). Bonner Biblische Beiträge 138. Berlin: Philo, 2004.

Botha, Phil J. "Psalm 91 and its Wisdom Connections." Old Testament Essays 25 (2012): 260-276.

Dahmen, Ulrich. “'Gepriesen sei der Herr, der Gott Israels, vom Anfang bis ans Ende der Zeiten' (Ps 106,48). Beobachtungen zur Entstehungsgeschichte des Psalters im vierten und fünften Psalmenbuch.” Biblische Zeitschrift 49 (2005): 1-25.

Gosse, Bernard. "Le parallélisme synonymique hsd 'mwnh, le Ps 89 et les réponses du quatrième livre du Psautier, Ps 90-106." Zeitschrift für die Alttestamentliche Wissenschaft 122 (2010): 185-198. https://doi.org/10.1515/zaw.2010.014.

Hossfeld, Frank-Lothar and Erich Zenger. Psalmen 51-100. Herders Theologischer Kommentar zum Alten Testament (HThK.AT), Freiburg: Herder, 2000.

Howard, David M., Jr. “A Contextual Reading of Psalms 90-94.” Pages 108-123 in The Shape and Shaping of the Psalter. Edited by J. Clinton McCann. Journal for the Study of the Old Testament Supplement Series 159. Sheffield: Sheffield Academic Press, 1993.

Howard, David M., Jr. The Structure of Psalms 93-100. Biblical and Judaic Studies from the University of California, San Diego 5. Winona Lake, IN: Eisenbrauns, 1997.

Howard, David M., Jr. "Psalm 94 among the Kingship-of-Yhwh Psalms." Catholic Biblical Quarterly 61 (1999): 667-685.

Jeremias, Jörg. Das Königtum Gottes in den Psalmen. Israels Begegnung mit dem kanaanäischen Mythos in den Jahwe-König-Psalmen. Forschungen zur Religion und Literatur des Alten und Neuen Testaments 141. Göttingen: Vandenhoeck \& Ruprecht, 1987. https://doi.org/10.13109/9783666538209.50.

Koenen, Klaus. Jahwe wird kommen, zu herrschen über die Erde. Ps 90-110 als Komposition. Bonner Biblische Beiträge 101. Weinheim: Beltz Athenäum, 1995.

Krüger, Thomas. "Psalm 90 und die 'Vergänglichkeit des Menschen'." Biblica 75 (1994): 191-219.

Labuschagne, Casper J. "Significant Sub-Groups in the Book of Psalms: A New Approach to the Compositional Structure of the Psalter." Pages 623-634 in The Composition of the Book of Psalms. Edited by Erich Zenger. Bibliotheca Ephemeridum Theologicarum Lovaniensium 238. Leuven: Peeters, 2010.

Leene, Henk. "The Coming of YHWH as King: The Complementary Character of Psalms 96 and 98." Pages 211-228 in Unless Some One Guide Me .... Festschrift for Karel A. Deurloo. Edited by Janet W. Dyk et al. Amsterdamse Cahiers voor Exegese van de Bijbel en zijn Tradities Supplement Series 2. Maastricht: Shaker, 2001.

Lescow, Theodor. "Die literarische Struktur des Psalms 100." Biblische Notizen 110 (2001): 38-41.

Leuenberger, Martin. Konzeptionen des Königtums Gottes im Psalter. Untersuchungen zu Komposition und Redaktion der theokratischen Bücher IV-V im Psalter. Abhandlungen zur Theologie des Alten und Neuen Testaments 83. Zürich: Theologischer Verlag, 2004.

Lugt, Pieter van der. Rhetorical Criticism and the Poetry of the Book of Job. Oudtestamentische Studiën 32. Leiden: Brill, 1995. 
Lugt, Pieter van der. Cantos and Strophes in Biblical Hebrew Poetry: With Special Reference to the First Book of the Psalter. Oudtestamentische Studiën 53. Leiden: Brill, 2006.

Lugt, Pieter van der. "'Ik ga voor u uit ...': Retorische structuur en numerieke perfectie in Jesaja 44,24-45,8." Pages 73-86 in Studies uit de Kamper School opgedragen aan Willem van der Meer. Edited by Klaas Spronk et al. Bergambacht: 2VM, 2010.

Lugt, Pieter van der. Cantos and Strophes in Biblical Hebrew Poetry II: Psalms 42-89. Oudtestamentische Studiën 57. Leiden: Brill, 2010. https://doi.org/10.1163/ej. 9789004182004.i-570.

Lugt, Pieter van der. Cantos and Strophes in Biblical Hebrew Poetry III: Psalms 90150 and Psalm 1. Oudtestamentische Studiën 63. Leiden: Brill, 2014. https://doi. org/10.1163/9789004262799.

Robertson, O. Palmer. The Flow of the Psalms. Discovering their Structure and Theology. Phillipsburg, NJ: P\&R Publishing, 2015.

Schnocks, Johannes. Vergänglichkeit und Gottesherrschaft. Studien zu Psalm 90 und dem vierten Psalmenbuch. Bonner Biblische Beiträge 140. Berlin: Philo, 2002.

Tate, Marvin E. Psalms 51-100. Word Biblical Commentary 20. Dallas, TX: Word Books, 1990.

Zenger, Erich. "Das Weltenkönigtum des Gottes Israel (Ps. 96-106).” Pages 151-178 in Der Gott Israels und die Völker. Untersuchungen zum Jesajabuch und zu den Psalmen. Edited by Norbert Lohfink and Erich Zenger. Stuttgarter Bibelstudien 154. Stuttgart: Katholisches Bibelwerk, 1994.

Zenger, Erich. "Theophanien des Königsgottes JHWH: Transformationen von Psalm 29 in den Teilkompositionen Ps 28-30 und Ps 93-100." Pages 407-442 in The Book of Psalms. Composition and Reception. Edited by Peter W. Flint and Patrick D. Miller. Supplements to Vetus Testamentum 99 / Formation and Interpretation of Old Testament Literature 4. Leiden: Brill, 2005. https://doi.org/10.1163/ 9789047414797_022.

Dr Pieter van der Lugt, Dokkum, The Netherlands, Email: p_vdlugt@ hotmail.com. 


\section{APPENDIX: THE STRUCTURAL FUNCTION OF THE NUMBER 11 IN CLASSICAL HEBREW POETRY}

\section{Psalms consisting of a multiple of 11 words}

- Ps 37 (an alphabetic acrostic): $27 \times \mathbf{1 1}$ words.

- Ps 38: $15 \times \mathbf{1 1}$ words (and $\mathbf{1 1}$ strophes).

- Pss 42-43: $17 \times 11$ words.

- Ps 55: $17 \times \mathbf{1 1}$ words (and $\mathbf{1 1}$ strophes).

- Ps 59: $13 \times \mathbf{1 1}$ words.

- Ps 60: $8 \times 11$ words.

- Ps 62: $10 \times 11$ words.

- Ps 63: $8 \times 11$ words.

- Ps 70: $4 \times 11$ words.

- Ps 78: $48 \times \mathbf{1 1}$ words (and $\mathbf{7 7}>\mathbf{1 1 . 3 3 . 3 3}$ lines).

- Ps 112 (an alphabetic acrostic): $7 \times \mathbf{1 1}$ words (and $\mathbf{2 2}$ cola).

- Ps 150: $3 \times \mathbf{1 1}$ words; Cantos I and II $>\mathbf{1 1 + 2 2}$ words $(>\mathbf{5 2}+\mathbf{1 0 4}=2 \times \mathbf{2 6}+4 \times \mathbf{2 6}$ letters). ${ }^{62}$

\section{The number 11 highlighting the rhetorical centre}

- Ps 18: v. $26 b$ (עם גבר תמים תתמם) > 5מם V+1+55 cola; note ('to be complete'; cf. Ps 64).

- Ps 25 (an alphabetic acrostic): v. 11b (וסלחת לעוני כי רב הוא) > 22+1+22 cola; 11 strophes and 11× יהוה (cf. Ps 94).

- Ps 34 (an alphabetic acrostic): v. 12b (יראת יהוה אלמדכם) > 77+3+77 words; 11 strophes, 22 lines, $\mathbf{4 4}$ cola.

- Ps 37 (an alphabetic acrostic): v. 21a (לוה רשע ולא ישלם) > 44+1+44 cola; 27×11 words.

- Ps 56: v. 9a (נדי ספרתה אתה) > 15+1+15 cola, 11 letters; the verb ספרתה is the centre of the colon in terms of letters (> 3+5+3 letters); note $\sqrt{ }$ ('to count').

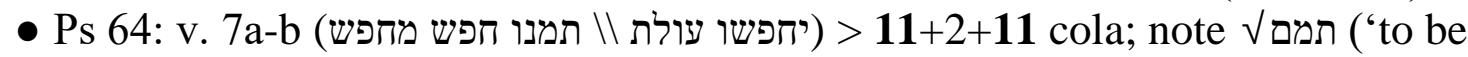
complete'; cf. Ps 18).

- Ps 66: v. 11b (שמת מועקה במתנינו) > 22+1+22 cola; centre of the middle strophe vv. 10-12 (< ('trammel') probably points to the device for inclusion.

- Ps 74: v. 12 (ואלהים מלכי מקדם \פו ועל ישועות בקרב הארץ) > 11+1+11 lines; v. 12 is the only line in which God is spoken about in the third person; note also the noun קרב ('inner part').

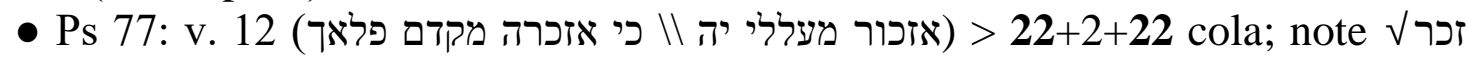
and cf. Ps. 78,35a (> 81+1+81 cola).

- Ps 79: v. 7 (17+2+17 cola)> 11+11 letters; v. 7 stands out in the psalm by the parallelism within the line.

62 Apart from Ps 117, the shortest psalm is Ps 150 with $3 \times \mathbf{1 1}$ words, while apart from Ps 119 , the longest psalm is Ps 78 with $48 \times \mathbf{1 1}$ words. 
- Ps 89: vv. 25-26 (<12+1+12 strophes $)>\mathbf{1 1}$ words; the strophe also stands out in the psalm because each of the four cola ends with the suffix of the third person singular (1-; cf. below about Isa 45:2 in the poem Isa 44:24-45:8).

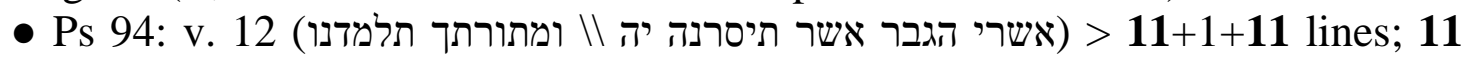

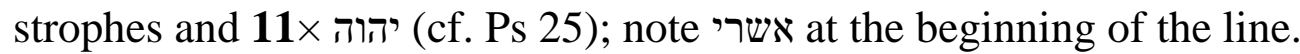

- Ps 137: vv. 5-6b > 11+4+11 cola; the central cola have $\mathbf{1 1}$ words.

- Ps 146: v. 6c (השמר אמת לעולם) > 11+1+11 cola.

- 1 Sam 2:1-10 (Song of Hanna): v. 6a (יהוה ממית ומחיה) > 55+3+55 words.

\section{The number 11 determining the rhetorical design of Isa 44:24-45:8}

The poem Isa 44:24-45:8 consists of $\mathbf{1 1}$ strophes and has $15 \times \mathbf{1 1}$ words. The middle strophe is 45:2 ( $<5+1+5$ strophes); this strophe has exactly 11 words. Additionally, on word level the strophe is once again the centre of the poem because it is flanked by multiples of $\mathbf{1 1}$ words, $\mathbf{7 7}=\mathbf{7 \times 1 1}$ words: $44: 24$ 45:1.45:2.45:3-8 > 77+11+77 words. The central strophe 45:2 also stands out in the poem because it is here that God for the first time straightforwardly addresses Cyrus; and it is only in this strophe that each colon concludes with a verb in the imperfect of the first person singular (cf. above about Ps 89:25-26). In the first canto (44:24-28) there are also 11 participles which sing the praises of God (Labuschagne). 44:26a-b is the middle line of this first canto. This line is enveloped by the verb forms ('who upholds', referring to God) and ישלים ('he performs', with subject God); in gematria the numerical value of these words is $55(5 \times 11)$ and $66(6 \times 11)$ respectively. ${ }^{63}$

63 See Pieter van der Lugt, “"Ik ga voor u uit ...': Retorische structuur en numerieke perfectie in Jesaja 44,24-45,8," in Studies uit de Kamper School opgedragen aan Willem van der Meer (ed. Klaas Spronk et al.; Bergambacht: 2VM, 2010), 73-86. 